\title{
Interstitial pulmonary fibrosis with and without associated collagen vascular disease: results of a two year follow up
}

\author{
C Agustí, A Xaubet, J Roca, A G N Agusti, R Rodriguez-Roisin
}

\begin{abstract}
Background Interstitial pulmonary fibrosis is a disease with a highly variable clinical course. To ascertain if an inadequate selection of patients might explain part of this variability, two different groups of patients with interstitial pulmonary fibrosis, those with the "lone" form of the disease (LIPF) and those with associated collagen vascular disorders (AIPF), were studied separately.

Methods Twenty consecutive patients (nine with LIPF and 11 with AIPF) were included. Their clinical and radiographic findings and results of pulmonary function tests, gallium-67 lung scanning, and cellular analysis of bronchoalveolar lavage fluid were compared at diagnosis. Moreover, the evolution of LIPF and AIPF was contrasted after a follow up of two years, both groups having received a similar treatment regimen of corticosteroids.
\end{abstract}

Results At enrolment, patients with LIPF and AIPF were of similar age, and had similar symptons and derangement of lung function, but patients with LIPF presented with finger clubbing, more obvious radiographic abnormalities, and a greater percentage of eosinophils in bronchoalveolar lavage fluid. Two years later, patients with LIPF had significantly decreased FVC, FEV , TLC, TLCO, and $\mathbf{P a O}_{2}$. By contrast, lung function remained unaltered in patients with AIPF. Similarly, when the percentage change from entry to the study was compared, patients with LIPF showed a significant decrease in FVC, $\mathrm{FEV}_{1}$, and $\mathrm{PaO}_{2}$. Conclusions Unlike the patients with AIPF, those with LIPF showed a deterioration in lung function and developed further restrictive impairment and poorer gas exchange. This has implications in their clinical management.

(Thorax 1992;47:1035-1040)

Interstitial pulmonary fibrosis is one of the most common and disabling interstitial lung disorders. ${ }^{1}$ Different studies have shown that the clinical course, as well as the response to treatment and prognosis, is highly variable. ${ }^{2-7}$ One of the reasons for this variability may be the inadequate characterisation of patients Usually, patients with the "lone" form of interstitial pulmonary fibrosis (LIPF) (also called cryptogenic fibrosing alveolitis) and those with interstitial pulmonary fibrosis associated with collagen vascular disorders (AIPF) are studied as a mixed group. Traditionally, it is believed that these disorders have similar clinical, radiographic, and morphological findings and lung function..$^{8-11}$ In recent years, there has been increasing awareness that the natural history of these two types of pulmonary fibrosis might be different. ${ }^{12}$ Moreover, recent histopathological and immunocytological studies tend to support the idea that the pathogenesis of pulmonary fibrosis may also have different mechanisms if associated with a collagen vascular disorder. ${ }^{13-16}$

We have compared clinical and radiographic findings, lung function, and indices of inflammation (gallium-67 lung scanning, and bronchoalveolar lavage cell counts) at diagnosis in patients with LIPF and with AIPF. Similarly, we have noted any changes over a follow up period of two years.

\section{Patients and methods}

PATIENTS WITH LIPF

We studied nine consecutive patients. Table 1 reports the principal anthropometric and clinical findings. The diagnosis was confirmed by open lung biopsy in four cases. One subject had a familial type of interstitial pulmonary fibrosis and four refused a biopsy. These five patients were diagnosed according to the clinical criteria of Turner-Warwick et $a l^{4}$-namely, widespread, persistent bilateral radiographic shadowing; widespread, persisting crackles; and no exposure to an external fibrogenic agent and no positive plasma precipitin results. Supportive but not obligatory criteria were finger clubbing and a restrictive ventilatory defect. Computer tomography was not used in diagnosis.

\section{PATIENTS WITH AIPF}

Eleven patients with collagen vascular disease were included. Six had diffuse scleroderma, three rheumatoid arthritis, and two dermatomyostis. The diagnosis of collagen vascular disease was made on the basis of well established criteria. ${ }^{17-19}$

The population included in this study represents consecutive patients seen in our department with LIPF or AIPF from January 1985 to March 1989. None of the patients died 
Table 1 Clinical, radiological, and inflammatory variables in patients at enrolment

\begin{tabular}{|c|c|c|c|c|c|c|c|c|c|c|c|c|c|}
\hline \multirow{2}{*}{$\begin{array}{l}\text { Patient } \\
\text { No }\end{array}$} & \multirow[b]{2}{*}{ Sex } & \multirow[b]{2}{*}{$\begin{array}{l}A g e \\
(y)\end{array}$} & \multirow[b]{2}{*}{$\begin{array}{l}\text { Height } \\
(m)\end{array}$} & \multirow[b]{2}{*}{ Smoking } & \multirow[b]{2}{*}{$\begin{array}{l}\text { Disease } \\
\text { type }\end{array}$} & \multirow[b]{2}{*}{$\begin{array}{l}\text { Dyspnoea } \\
\text { (score) }\end{array}$} & \multirow[b]{2}{*}{ Clubbing } & \multirow[b]{2}{*}{$\begin{array}{l}\text { Crackles } \\
\text { (grade) }\end{array}$} & \multirow{2}{*}{$\begin{array}{l}\text { Chest } \\
x \text { ray } \\
\text { film }\end{array}$} & \multirow{2}{*}{$\begin{array}{l}\text { Gallium-67 } \\
\text { (LHI) }\end{array}$} & \multicolumn{3}{|l|}{$B A L$} \\
\hline & & & & & & & & & & & $\% L$ & $\% N$ & $\% E$ \\
\hline \multicolumn{14}{|c|}{ Patients with LIPF } \\
\hline 1 & $\mathbf{M}$ & 53 & 1.63 & Ex & LIPF & 2 & Yes & 4 & 2 & NA & 4 & 11 & 0 \\
\hline 2 & $\mathrm{~F}$ & 43 & 1.56 & No & LIPF & 3 & Yes & 0 & 3 & 0.48 & 58 & 5 & 3 \\
\hline 3 & $\mathbf{M}$ & 52 & $1 \cdot 60$ & Yes & LIPF & 1 & Yes & 4 & 3 & 0.86 & 1 & 9 & 4 \\
\hline 4 & $\mathbf{M}$ & 65 & 1.57 & Ex & LIPF & 2 & Yes & 3 & 2 & 0.53 & 2 & 10 & 0 \\
\hline 5 & $\mathrm{~F}$ & 66 & 1.58 & No & LIPF & 1 & Yes & 3 & 2 & 0.54 & 6 & 6 & 0 \\
\hline 6 & $M$ & 67 & 1.60 & Ex & LIPF & 1 & Yes & 4 & 2 & 0.60 & 7 & 11 & 4 \\
\hline 7 & $\mathrm{~F}$ & 59 & 1.59 & No & LIPF & 1 & No & 3 & 1 & NA & NA & $\mathrm{NA}$ & NA \\
\hline 8 & $M$ & 42 & 1.66 & Yes & LIPF & 1 & Yes & 4 & 2 & 0.45 & 6 & 11 & 2 \\
\hline 9 & $\mathrm{~F}$ & 63 & 1.54 & No & LIPF & 3 & Yes & 4 & 2 & $0 \cdot 72$ & 40 & 7 & 2 \\
\hline $\begin{array}{l}\text { Mean } \\
\text { (SD) }\end{array}$ & $\begin{array}{l}\text { Total } \\
5 \mathrm{M} / 4 \mathrm{~F}\end{array}$ & $\begin{array}{l}57 \\
(10)\end{array}$ & $\begin{array}{l}1.59 \\
(0)\end{array}$ & & & $\begin{array}{l}1 \cdot 6 \\
(1)\end{array}$ & $\begin{array}{l}\text { Total } \\
8 \text { Yes/ } \\
1 \mathrm{No}^{\star \star \star}\end{array}$ & $\begin{array}{l}3 \cdot 2 \\
(1)\end{array}$ & $\begin{array}{l}2 \cdot 1 \\
(0)^{\star \star \star}\end{array}$ & $\begin{array}{l}0 \cdot 60 \\
(0 \cdot 1)\end{array}$ & $\begin{array}{l}15 \\
(21)\end{array}$ & $\begin{array}{l}9 \\
(2)\end{array}$ & $\begin{array}{l}2 \\
(2)^{\star \star}\end{array}$ \\
\hline \multicolumn{14}{|c|}{ Patients with AIPF } \\
\hline 10 & $M$ & 53 & 1.66 & Yes & Sc & 0 & No & 0 & 1 & $0 \cdot 24$ & 1 & 5 & 0 \\
\hline 11 & $\mathbf{F}$ & 42 & 1.54 & No & Sc & 2 & No & 1 & 1 & 0.43 & 5 & 1 & 0 \\
\hline 12 & $\mathrm{~F}$ & 60 & 1.41 & No & Sc & 1 & No & 1 & 1 & 0.35 & NA & NA & NA \\
\hline 13 & $\mathrm{~F}$ & 52 & 1.62 & No & Sc & 1 & No & 4 & 2 & 0.34 & 18 & 2 & 0 \\
\hline 14 & $\mathrm{~F}$ & 46 & 1.54 & No & Sc & 1 & No & 3 & 1 & 0.60 & 6 & 6 & 0 \\
\hline 15 & $\mathbf{M}$ & 48 & 1.65 & Yes & Sc & 0 & No & 3 & 1 & NA & NA & NA & NA \\
\hline 16 & $\mathbf{M}$ & 62 & 1.73 & Ex & RA & 1 & No & 3 & 1 & 0.56 & 13 & 6 & 0 \\
\hline 17 & $\mathbf{M}$ & 71 & $1 \cdot 78$ & Yes & RA & 0 & No & 0 & 1 & 0.51 & 5 & 3 & 0 \\
\hline 18 & $\mathbf{M}$ & 58 & 1.72 & Yes & RA & 0 & No & 0 & 1 & 0.65 & 2 & 0 & 0 \\
\hline 19 & $\mathbf{F}$ & 72 & 1.51 & No & Dms & 2 & No & 3 & 2 & 0.45 & 6 & 18 & 0 \\
\hline 20 & $\mathbf{F}$ & 51 & 1.54 & No & Dms & 3 & No & 4 & 1 & 0.53 & 30 & 1 & 0 \\
\hline $\begin{array}{l}\text { Mean } \\
\text { (SD) }\end{array}$ & $\begin{array}{l}\text { Total } \\
5 \mathrm{M} / 6 \mathrm{~F}\end{array}$ & $\begin{array}{l}56 \\
(10)\end{array}$ & $\begin{array}{l}1 \cdot 63 \\
(1)\end{array}$ & & & $\begin{array}{l}1 \\
(1)\end{array}$ & $\begin{array}{l}\text { Total } \\
11 \mathrm{No}^{\star \star \star}\end{array}$ & $\begin{array}{l}2 \\
(2)\end{array}$ & $\begin{array}{l}1 \cdot 1 \\
(0)^{\star \star \star}\end{array}$ & $\begin{array}{l}0 \cdot 47 \\
(0 \cdot 1)\end{array}$ & $\begin{array}{l}10 \\
(9)\end{array}$ & $\begin{array}{l}5 \\
(5)\end{array}$ & $0^{\star \star \star}$ \\
\hline
\end{tabular}

$\star \star \mathrm{p}<0.01 ;{ }^{\star \star \star} \mathrm{p}<0.001$.

M-male; F-female; Ex-ex-smoker; LHI-lung hepatic index; Sc-scleroderma; RA-rheumatoid arthritis; Dms-dermatomyositis; BALbronchoalveolar lavage fluid; NA-not available; L-lymphocytes; N-neutrophils; E-eosinophils.

during the follow up period. The entire study was performed as part of the full diagnostic assessment and outpatient care protocol for interstitial lung disease in our centre. Accordingly, all patients were informed of the characteristics and nature of the procedures performed and all gave consent. All examinations took place when the diagnosis of pulmonary fibrosis was first made. None of them had received previous steroid or immunosuppressive treatment.

\section{CLINICAL AND RADIOGRAPHIC ASSESSMENT}

An extended Epidemiological Standardisation Project questionnaire was administered to each patient and a full physical examination was carried out. ${ }^{20}$ The severity of dyspnoea and the presence of inspiratory crackles were graded according to criteria reported previously. ${ }^{21}$

Posteroanterior chest radiographs were evaluated according to the International Labour Office/International Union Against Cancer 1980 classification of pneumoconioses by two blinded and independent readers. The final assessment of each film represented the median interpretation of these two readers. ${ }^{21}$

\section{PULMONARY FUNCTION TESTS}

In each patient, forced spirometric indices, slow vital capacity (HP 47804A Pulmonary System Desk; Hewlett-Packard, Waltham, MA), thoracic gas volume and airway resistance (Body test; E Jaeger, Würzburg, Germany), and the single breath carbon monoxide transfer factor (Resparamater Model A; PK Morgan Ltd, Chatham, Kent, UK) were measured. The reference values used in this study were those of our own laboratory. ${ }^{20223}$ All but one patient had arterial blood gases measured at rest while breathing air (IL 1302 Instrument Laboratories, Milano, Italy). The alveolar-arterial $\mathrm{PO}_{2}$ difference $\left(\mathrm{A}-\mathrm{aDO}_{2}\right)$ was calculated by using the standard formula with a respiratory exchange ratio $(R)$ of $0 \cdot 8$.

\section{GALLIUM LUNG SCAN}

Gallium lung scans were performed with a gamma camera (4/15 Picker) connected on line to a digital computer, 48 hours after the intravenous administration of 2 to $5 \mathrm{mCi}$ of gallium citrate. The quantified lung activity was then compared with hepatic activity and a lung hepatic index obtained. An increase of pulmonary parenchymal uptake of gallium- 67 was considered when the lung hepatic index was higher than $0 \cdot 25 .^{24}$

\section{BRONCHOALVEOLAR LAVAGE}

Bronchoalveolar lavage was performed by flexible fibreoptic bronchoscopy with a total volume of $150 \mathrm{ml}$ of $0.9 \%$ sterile saline in three $50 \mathrm{ml}$ aliquots as previously described. ${ }^{21}$ The normal differential count in our laboratory is: macrophages 94 (2)\%, lymphocytes 4.8 (3)\%, neutrophils $1 \cdot 3(0 \cdot 8) \%$, eosinophils $0 \cdot 1(0 \cdot 2) \%$, and mast cells $0(0) \%{ }^{21}$

\section{TREATMENT AND FOLLOW UP}

At the time of the diagnosis, none of the patients had received steroids; thereafter, they received prednisone $(1 \mathrm{mg} / \mathrm{kg} /$ day; maximum, $100 \mathrm{mg} /$ day) for four to six weeks. Treatment was continued on the lowest dose of prednisone (range 5-30 mg/day) to maintain both maximal 
Table 2 Pulmonary function tests at enrolment

\begin{tabular}{|c|c|c|c|c|c|c|c|c|c|}
\hline $\begin{array}{l}\text { Patient } \\
\text { No }\end{array}$ & $\begin{array}{l}F V C \\
(l(\%))\end{array}$ & $\begin{array}{l}F E V_{1} / F V C \\
(\%)\end{array}$ & $\begin{array}{l}T L C \\
(l(\%))\end{array}$ & $\begin{array}{l}R V / T L C \\
(\%)\end{array}$ & $\begin{array}{l}T L C O^{\star} \\
\left(\mathrm{mmol} \mathrm{min}^{-1} \mathrm{kPa}^{-1}(\%)\right)\end{array}$ & $\begin{array}{l}\text { TLCO/VA } \\
\left(\mathrm{mmol} \mathrm{min}^{-1} \mathrm{kPa}^{-1} \mathrm{l}^{-1}(\%)\right)\end{array}$ & $\begin{array}{l}\mathrm{PaO}_{2} \\
(\mathrm{kPa})\end{array}$ & $\begin{array}{l}\mathrm{PaCO}_{2} \\
(\mathrm{kPa})\end{array}$ & $\begin{array}{l}A-a \mathrm{DO}_{2} \\
(\mathrm{kPa})\end{array}$ \\
\hline \multicolumn{10}{|c|}{ Patients with LIPF } \\
\hline 1 & $2 \cdot 4(68)$ & 67 & $4.8(89)$ & 44 & $7 \cdot 5(80)$ & 2.0 & $9 \cdot 4$ & $5 \cdot 2$ & 3.9 \\
\hline 2 & $2 \cdot 1(67)$ & 85 & $3 \cdot 2(74)$ & 19 & $2 \cdot 7(38)$ & $0.9(50)$ & $12 \cdot 3$ & $4 \cdot 4$ & $1 \cdot 3$ \\
\hline 3 & $3.3(81)$ & 76 & $5.0(98)$ & 30 & $5 \cdot 7(67)$ & $1 \cdot 1(72)$ & 9.0 & $5 \cdot 4$ & 3.9 \\
\hline 4 & $3.0(103)$ & 64 & $4 \cdot 1(57)$ & 34 & $5 \cdot 7(85)$ & $1.5(77)$ & $8 \cdot 0$ & $4 \cdot 0$ & $6 \cdot 9$ \\
\hline 5 & $2 \cdot 1(79)$ & 84 & $3 \cdot 1(65)$ & 32 & $3 \cdot 2(47)$ & $1.1(65)$ & $11 \cdot 0$ & $4 \cdot 8$ & $2 \cdot 9$ \\
\hline 6 & $3 \cdot 0(78)$ & 80 & $5.5(83)$ & 44 & $3.7(48)$ & $1 \cdot 0(60)$ & $11 \cdot 7$ & 4.9 & 1.9 \\
\hline 7 & $1.9(60)$ & 85 & $2.9(56)$ & 26 & $4 \cdot 8(63)$ & $1.8(102)$ & $9 \cdot 8$ & $5 \cdot 0$ & 3.9 \\
\hline 8 & $2.5(55)$ & 88 & $4 \cdot 0(60)$ & 34 & $3.6(35)$ & $1.0(59)$ & $10 \cdot 9$ & $4 \cdot 4$ & $3 \cdot 6$ \\
\hline 9 & $1 \cdot 7(61)$ & 71 & $4 \cdot 4(89)$ & 59 & $4 \cdot 3(59)$ & $1.6(81)$ & $7 \cdot 6$ & $5 \cdot 3$ & $5 \cdot 7$ \\
\hline $\begin{array}{l}\text { Mean } \\
\text { (SD) }\end{array}$ & $\begin{array}{l}2 \cdot 4(0.6) \\
(72(15))\end{array}$ & $78(9)$ & $\begin{array}{l}4 \cdot 1(0 \cdot 9) \\
(75(16))\end{array}$ & $36(12)$ & $\begin{array}{l}4 \cdot 6(1.5) \\
(58(18))\end{array}$ & $\begin{array}{l}1.4(0 \cdot 4) \\
(77(25))\end{array}$ & $10(1 \cdot 6)$ & $4.8(0.4)$ & $3.8(1.6)$ \\
\hline \multicolumn{10}{|c|}{ Patients with AIPF } \\
\hline 10 & $4.3(98)$ & 68 & $6.0(106)$ & 28 & $5 \cdot 0(52)$ & $0.9(56)$ & $12 \cdot 4$ & $5 \cdot 0$ & $1 \cdot 0$ \\
\hline 11 & $1.5(45)$ & 88 & $2 \cdot 3(54)$ & 32 & $3 \cdot 1(50)$ & $1.6(83)$ & $9 \cdot 0$ & $4 \cdot 7$ & $4 \cdot 9$ \\
\hline 12 & $1.8(78)$ & 75 & NA ( ) & NA & $4 \cdot 0(60)$ & $1.7(91)$ & $10 \cdot 6$ & $4 \cdot 0$ & $4 \cdot 1$ \\
\hline 13 & $2 \cdot 7(79)$ & 81 & $4 \cdot 1(77)$ & 35 & $5 \cdot 1(63)$ & $1.5(84)$ & 11.8 & $4 \cdot 9$ & 1.9 \\
\hline 14 & $2 \cdot 2(73)$ & 64 & $3.7(89)$ & 35 & $3.8(51)$ & $1.4(37)$ & 10.5 & $5 \cdot 4$ & $3 \cdot 2$ \\
\hline 15 & $3.6(81)$ & 76 & $5.7(86)$ & 37 & $9.9(105)$ & $2 \cdot 2(119)$ & NA & $\mathrm{NA}$ & NA \\
\hline 16 & $3 \cdot 1(65)$ & 66 & $4.9(62)$ & 36 & $6.5(68)$ & $1.6(99)$ & 10.0 & $5 \cdot 3$ & 4.9 \\
\hline 17 & $3.6(71)$ & 63 & $5.8(67)$ & 37 & $5.8(61)$ & $1.3(94)$ & 10.9 & $4 \cdot 7$ & $2 \cdot 8$ \\
\hline 18 & $4 \cdot 4(94)$ & 64 & $8 \cdot 4(109)$ & 47 & $8.0(83)$ & $1.3(81)$ & $10 \cdot 1$ & $5 \cdot 3$ & $3 \cdot 2$ \\
\hline 19 & $1.3(59)$ & 73 & $3.3(90)$ & 55 & 4.3 (71) & $2 \cdot 3(141)$ & $8 \cdot 6$ & $5 \cdot 3$ & $4 \cdot 7$ \\
\hline 20 & $2.0(64)$ & 85 & $3 \cdot 4(69)$ & 40 & $2.9(38)$ & $1.0(56)$ & $9 \cdot 2$ & 3.5 & $6 \cdot 3$ \\
\hline $\begin{array}{l}\text { Mean } \\
\text { (SD) }\end{array}$ & $\begin{array}{l}2 \cdot 8(1) \\
(73(15))\end{array}$ & $73(9)$ & $\begin{array}{l}4.8(1 \cdot 8) \\
(81(18))\end{array}$ & $38(8)$ & $\begin{array}{l}5 \cdot 3(2 \cdot 1) \\
(64(18))\end{array}$ & $\begin{array}{l}1.5(0.4) \\
(86(29))\end{array}$ & $10 \cdot 3(1.2)$ & $4 \cdot 8(0 \cdot 7)$ & $3.7(1.6)$ \\
\hline
\end{tabular}

FVC-forced vital capacity; $\mathrm{FEV}_{1}$ - forced expiratory volume in one second; TLC-total lung capacity; TLco-carbon monoxide transfer factor; VAalveolar volume; $\mathrm{PaO}_{2}$ - partial pressure of arterial oxygen; $\mathrm{PaCO}_{2}-$ partial pressure of arterial carbon dioxide; $\mathrm{A}-\mathrm{aDO}-\mathrm{alveolar}-\mathrm{arterial} \mathrm{PO}_{2}$ difference.

subjective and objective improvement. In general, the maintenance dose required was greater for patients with LIPF. No patient with LIPF or AIPF received immunosuppressive drugs throughout the period of the study, and no attempt was made to repeat the initial high dose course of steroids. Only two patients with AIPF, without symptoms and with normal lung function (patients 15 and 18), did not receive steroids because of specific risks of adverse effects. Patients with LIPF were treated continuously during the two years of follow up. By contrast, one patient with AIPF (patient 10) refused steroids after six months of treatment when the disease seemed to be stable. Patients with AIPF were fully re-evaluated at 27 (5) months and patients with LIPF at 24 (3) months. The time difference was not significant. The evaluation was based on clinical, radiographic and physiological findings.

\section{STATISTICAL ANALYSIS}

Data are expressed as mean (SD). Results were tested by Mann-Whitney, Wilcoxon, and $\chi^{2}$ tests for differences between groups when appropriate. To determine the correlation between clinical, radiographic, and lung function data and bronchoalveolar lavage and gallium scan findings, Pearson's correlation coefficients were calculated.

\section{Results}

CLINICAL AND RADIOGRAPHIC TESTS, LUNG FUNCTION, AND INFLAMMATORY CHARACTERISTICS AT ENROLMENT

The distribution of age, sex, height, and smoking habits was similar in the two groups. At enrolment, all the patients with LIPF were dyspnoeic whereas four subjects with AIPF had no pulmonary symptoms. The overall severity of dyspnoea was, however, similar in the two groups. All but one of the patients with LIPF had finger clubbing, a finding not seen in any patient with AIPF ( $\mathrm{p}<0.001)$. Although all patients studied showed different grades of bilateral radiological shadowing, it was more pronounced in patients with LIPF. Thus only one of the subjects with LIPF had a radiographic score of 1 ; by contrast, nine out of 11 patients with AIPF had a score of $1(p<0.001)$ (table 1).

Table 2 lists the results of the lung function tests. Seven patients (four with LIPF and three with AIPF) had a restrictive ventilatory pattern, five (two with LIPF and three with AIPF) an obstructive pattern, and six a mixed or undefined pattern (two with LIPF and four with AIPF) (restrictive pattern: forced vital capacity (FVC) $<80 \%$, forced expiratory volume in one second $\left(\mathrm{FEV}_{1}\right) / \mathrm{FVC} \geqslant 70 \%$, and total lung capacity (TLC) $<80 \%$; obstructive pattern: $\mathrm{FEV}_{1}<80 \%$ and $\mathrm{FEV}_{1} /$ FVC $\leqslant 70 \%$ ). Spirometric values were normal in two patients (patients 3 and 15). Also reduced transfer factor, hypoxaemia, or increased $\mathrm{A}-\mathrm{aDO}_{2}$ were present in most of the patients in each group.

No differences were found for spirometric data, static lung volumes, diffusing capacity, and arterial blood gases between the groups.

We found an increase in the uptake of gallium- 67 by the lung parenchyma in 16 of the 17 patients in whom scanning was performed. The severity of active inflammation, as assessed by the uptake of gallium- 67 , was more pronounced in those cases with LIPF $(0.60(0 \cdot 1))$ than in those with AIPF $(0 \cdot 47(0 \cdot 1))$, but the 
Figure 1 Individual and mean (bold line) results for the most significant lung function tests (expressed as

$\%$ predicted). A, at enrolment; $B$, after two years. For abbreviations, see table 2.
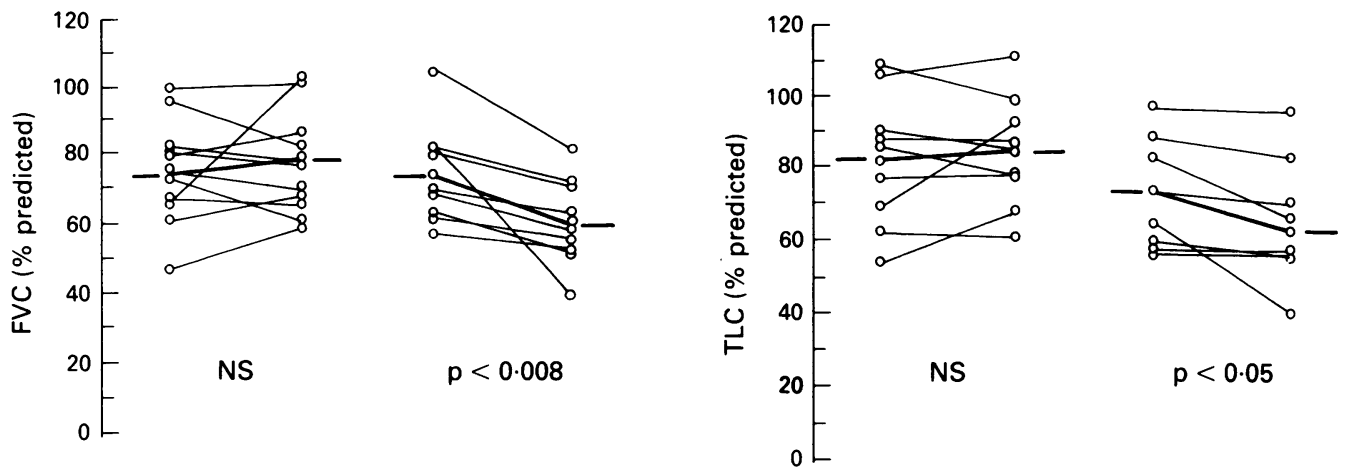

$p<0.05$

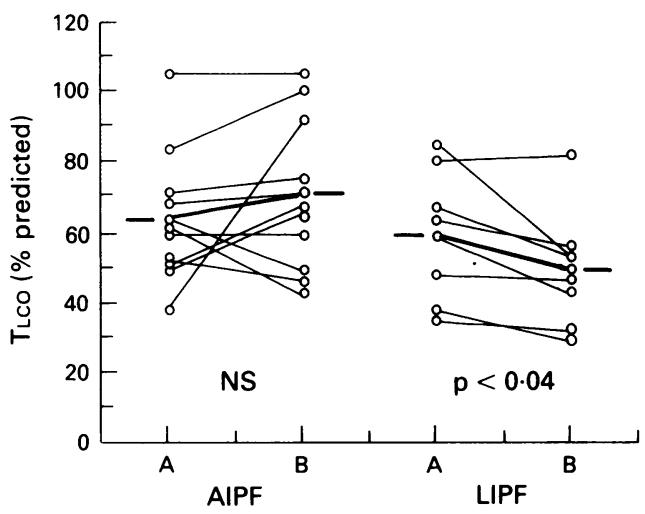

difference was not significant $(p=0 \cdot 06)$. Only two of the 17 patients in whom bronchoalveolar lavage was performed had a normal differential cell count (patients 11 and 18). We found variable degrees of lymphocytosis (lymphocytes $>12 \%$ ) and neurophilia (neutrophils $>3 \%$ ) in the two groups of patients. Whereas eosinophilia (eosinophils $>1 \%$ ) was a common finding in patients with LIPF (five subjects), it was absent in all patients with AIPF $(\mathrm{p}<0.01)$ (see table 1$)$.

FOLLOW UP OF PATIENTS WITH LIPF

Clinical and radiographic indices remained essentially unaltered two years after enrolment in LIPF patients as a group. Individually, dyspnoea was unchaged in four patients and worse in four others; the severity of crackles

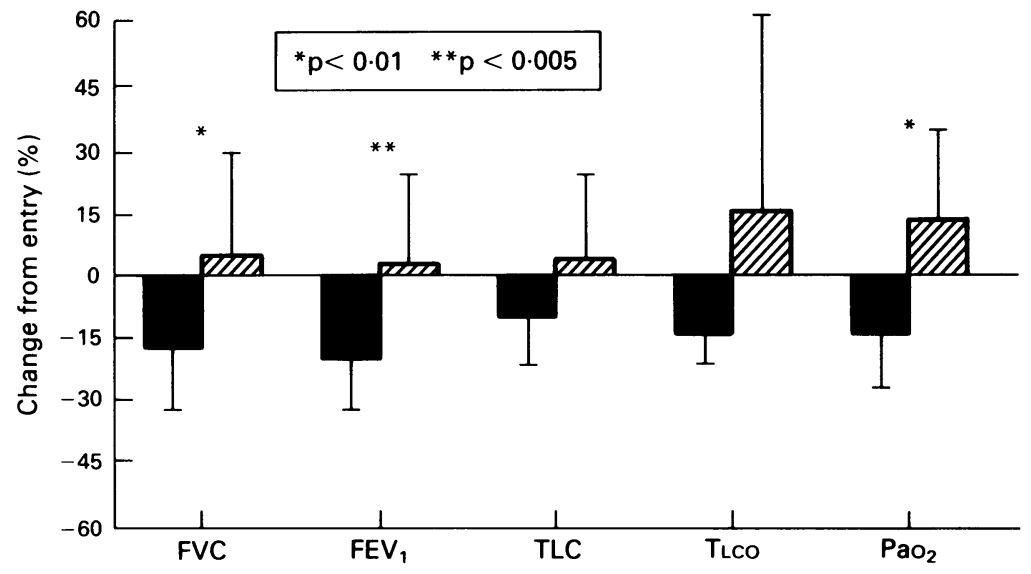

Figure 2 Percentage change from entry to the study in the most representative lung function tests (mean SD). Black bars, patients with LIPF; dashed bars, patients with AIPF. For abbreviations, see table 2.

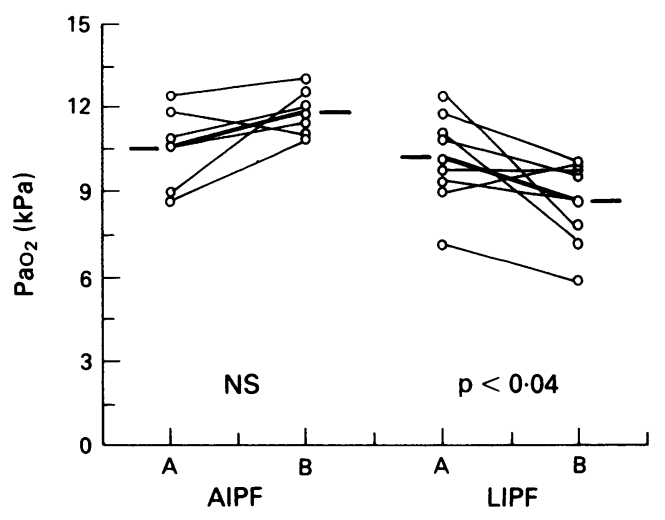

was the same in six patients and worse in only one; and the severity of radiographic shadowing was unchanged in five patients and worse in two. By contrast, most of the indices of lung function showed a substantial deterioration after two years of evolution. There was a significant decrease in FVC $(\mathrm{p}<0.002), \mathrm{FEV}_{1}$ $(\mathrm{p}<0.001)$, TLC $(\mathrm{p}<0.04)$, transfer factor $(\mathrm{p}<0.03)$, and $\mathrm{PaO}_{2}(\mathrm{p}<0.04)$.

\section{FOLLOW UP OF PATIENTS WITH AIPF}

As in patients with LIPF, clinical and radiographic findings for patients with AIPF remained virtually unchanged after two years. Individually the degree of dyspnoea was stable in eight patients and worse in two; the severity of crackles was unchanged in seven and worse in one. Finally, no patient showed a change in radiographic appearance of the lungs. Similarly, the evolution of indices of lung function after two years of follow up in patients with AIPF remained unchanged. Figure 1 W shows the changes from entry to the study for 0 the most representative lung function tests for the two groups of patients.

COMPARISON BETWEEN PATIENTS WITH LIPF AND AIPF

We compared the evolution of the indices of lung function ( $\%$ change from entry to the study) after two years. Patients with LIPF showed a significant decrease in FVC \& $(\mathrm{p}<0.01), \quad \mathrm{FEV}_{1} \quad(\mathrm{p}<0.005)$, and $\mathrm{PaO}_{2}$ $(\mathrm{p}<0.01)$ (figure 2$)$.

\section{Discussion}

The present study confirms that interstitial 
pulmonary fibrosis is a disorder with a variable clinical course. Whereas patients with LIPF seem to deteriorate, those with AIPF change less. This could partly explain both the variability and unpredictibility of the natural history of interstitial pulmonary fibrosis seen in studies in which these two groups of patients have been mixed together. ${ }^{34-1125}$ Although it could be argued that only a few patients evaluated had confirmation by biopsy, all fulfilled the common, well established, clinical criteria for the diagnosis of pulmonary fibrosis applied in many of the larger series reported. ${ }^{248}$

In the present study, patients with LIPF complained more often of dyspnoea and had a worse radiographic score at diagnosis. Although these findings initially suggest that the patients with LIPF had more advanced disease, several comments need to be made. Firstly, dyspnoea during physical effort may be easily underestimated in patients with AIPF because of limited mobility. ${ }^{26}$ Secondly, there were no differences in the severity of either dyspnoea or crackles between the two groups. Thirdly, it is accepted that pulmonary function indices are more sensitive and have a better correlation with the underlying lung pathology than pulmonary symptoms and chest radiographs. ${ }^{27}$ In this regard, our two groups of patients showed similar lung function at diagnosis, suggesting that they were at a comparable stage of their disease. Patients with either diagnosis showed a mild to moderate reduction in lung volumes with low transfer factor and mild hypoxaemia. Two years later, lung function in patients with LIPF had significantly deteriorated, whereas no evidence of disease progression was found in patients with AIPF, both groups having received comparable steroid treatment. In patients with LIPF, lung volumes decreased and there was further deterioration in gas exchange, suggesting a loss of alveolar units and reduced lung compliance. This would cause more ventilation-perfusion mismatch and also more diffusion limitation for oxygen. ${ }^{28}$ The lack of a significant change in $\mathrm{A}-\mathrm{aDO}_{2}$ in the presence of a further decrease in $\mathrm{PaO}_{2}$ may be explained by the errors inherent in its calculation (the respiratory exchange ratio $\mathrm{R}$ was assumed not to have altered, but $\mathrm{PaCO}_{2}$ tended to increase over the two years). On the other hand, patients with AIPF remained functionally stable after two years. It is accepted that the prognosis of patients with scleroderma and rheumatoid arthritis depends on the extent of visceral involvement. ${ }^{26}$ Several authors have shown that, although both acute and subacute progression may occur, the pulmonary interstitial process is not always progressive. ${ }^{2629} 30$ Indeed, three retrospective studies have shown that patients with scleroderma had no greater deterioration in vital capacity or transfer factor than that expected in healthy subjects over a three to five year follow up period. ${ }^{31-33}$ Similarly, although controlled studies are lacking, patients with pulmonary fibrosis and rheumatoid arthritis may follow an indolent course even with radiographic evidence of disease. ${ }^{26} 34$

Interestingly, in the present study one of the patients with AIPF with dermatomyositis showed a substantial clinical, radiographic, and functional improvement after two years of steroid treatment (patient 20). By contrast with patients with scleroderma and rheumatoid arthritis, patients with dermatomyositis can respond well to steroid treatment. ${ }^{35}{ }^{36}$ Although our results did not differ when the two patients with dermatomyositis were excluded, their different response to steroids suggests that the clinical course could also be different, depending on the specific type of underlying collagen vascular disorder.

The poorer outcome of patients with LIPF might be predicted by three findings at diagnosis. Firstly, by contrast with patients with AIPF, they had finger clubbing, a sign that has been associated with pulmonary angiogenesis and rapid progression of the disease. ${ }^{37}$ Secondly, patients with LIPF had a more substantial uptake of gallium- 67 by the lung parenchyma (although the difference was not significant), suggesting that they might have more severe interstitial inflammation. ${ }^{8}$ Thirdly, these patients showed a significant increase in eosinophils in bronchoalveolar lavage fluid compared with those with AIPF. Although the presence of increased numbers of eosinophils in bronchoalveolar lavage fluid from patients with AIPF is a well known finding, ${ }^{14}{ }^{38} 39$ some authors have shown that they have fewer than patients with LIPF. ${ }^{49}$ Furthermore, it has been shown that stable patients with AIPF without symptoms have a normal cell count in bronchoalveolar lavage fluid or variable increases in neutrophils or lymphocytes but they hardly ever have an increase in eosinophils. ${ }^{41-43} \mathrm{It}$ is known that eosinophils contain a powerful constellation of highly cytotoxic products potentially involved in the development of tissue damage. ${ }^{44}$ Indeed, recent reports have shown that the presence of increased eosinophils in bronchoalveolar lavage fluid from patients with LIPF or AIPF indicates a probable lack of response to steroids and also predicts deterioration in pulmonary function. ${ }^{10384145}$ Thus the presence of a significantly lower percentage of eosinophils in patients with AIPF might reflect a less active inflammatory process than in patients with LIPF.

In summary, our results show that lung function in patients with LIPF deteriorated over two years whereas in patients with AIPF it remained essentially unchanged, suggesting that the natural history of these two fibrotic disorders may be different. The presence of both finger clubbing and a greater percentage of eosinophils in bronchoalveolar lavage fluid from patients with LIPF at diagnosis could predict their subsequent deterioration. Further studies with a larger number of patients seem warranted to confirm these findings. This work was supported by a grant from Fondo de Research Training Fellowship from the Hospital Clinic, Barcelona.

1 Crystal RG, Bitterman PB, Rennard SI, Hance AJ, Keogh BA. Interstitial lung diseases of unknown cause. Disorders characterized by chronic inflammation of the lower respiratory tract. N Engl J Med 1984;310:154-66, 235-44. 
2 Crystal RG, Fulmer JD, Roberts WC, Moss ML, Line BR, Reynolds HY. Idiopathic pulmonary fibrosis: clinical, histologic, radiographic, physiologic, scintigraphic, cytologic and biochemical aspects. Ann Intern Med 1976;85:769-88.

3 Carrington CB, Gaensler EA, Coutu RE, Fitzgerald MX, Gupta RG. Natural history and treated course of usual and desquamative interstitial pneumonia. $N$ Engl J Med 1978;298:801-9.

4 Turner-Warwick M, Burrows B, Johnson A. Cryptogenic fibrosing alveolitis: clinical features and their influence on survival. Thorax 1980;35:171-80.

5 Crystal RG, Gadek JE, Ferrans VJ, Fulmer JD, Line BR, Hunninghake GW. Interstitial lung disease: current concepts of pathogenesis, staging and therapy. $A m \mathrm{~J} \mathrm{Med}$ 1981;70:542-68.

6 Raghu G. Idiopathic pulmonary fibrosis. A rational clinical approach. Chest 1987;92:148-54.

7 Panos RJ, Mortenson RL, Niccoli SA, King TE Jr. Clinical deterioration in patients with idiopathic pulmonary fibrosis: causes and assessment. Am J Med 1990;88: 396-404.

8 Line BR, Fulmer JD, Reynolds HY, et al. Gallium-67 citrate scanning in the staging of idiopathic pulmonary fibrosis: correlation with physiologic and morphologic features and bronchoalveolar lavage. Am Rev Respir Dis 1978;118: 355-65.

9 Haslam PL, Turton CWG, Lukoszek A, et al. Bronchoalveolar lavage fluid cell counts in cryptogenic fibrosing alveolitis and their relation to therapy. Thorax alveolitis and

10 Rudd RM, Haslam PL, Turner-Warwick M. Cryptogenic fibrosing alveolitis. Relationships of pulmonary physiology and bronchoalveolar lavage to response to treatment and prognosis. Am Rev Respir Dis 1981;124: $1-8$.

11 Turner-Warwick M, Haslam PL. The value of serial bronchoalveolar lavages in assessing the clinical progress of patients with cryptogenic fibrosing alveolitis. Am Rev Respir Dis 1987;135:26-34.

12 Hay FG, Turner-Warwick M. Cryptogenic fibrosing alveolitis (idiopathic pulmonary fibrosis): review of certain features leading to new areas of investigation. In: Flenley DC Petty TI, eds. Recent advances in respiratory medicine. Edinburgh: Churchill Livingston 1986;131-51.

13 Nagai S, Fujimura N, Hirata T, Izumi T. Differentiation between idiopathic pulmonary fibrosis and interstitial pneumonia associated with collagen vascular diseases by comparison of the ratio of OKT4 + cells and OKT8 + cells in BALF T lymphocytes. Eur J Respir Dis 1985;67: $1-9$.

14 Owens GR, Paradis IL, Gryzan S, Medsger TA, Follansbee WP, Klein GA, Dauber JH. Role of inflammation in the lung disease of systemic sclerosis: comparison with idiopathic pulmonary fibrosis. J Lab Clin Med 1986; 107:253-60.

15 Yousem SA, Colby TB, Carrington CB. Lung biopsy in rheumatoid arthritis. Am Rev Respir Dis 1985;131:770-7.

16 Tazelaar HD, Viggiano W, Pickersgill J, Colby TV. Interstitial lung disease in polymyositis and dermatomyositis. Am Rev Respir Dis 1990;141:727-33.

17 Subcommittee for scleroderma. Criteria of the American Rheumatism Association Diagnostic and Therapeutic. Criteria Committee: preliminary criteria for the classification of systemic sclerosis (scleroderma). Arthritis Rheum 1980;23:581-90.

18 Ryckewaert A. Polyarthrite rhumatoide. In: Kahn MF, Peltier AP, eds. Maladies dites systémiques. 2nd ed. Paris: Flammarion, 1986;135:168.

19 Serratrice G, Schiano A. Dermatopolymyosites. In: Kahn MF, Peltier AP, eds. Maladies dites systémiques. 2nd ed. Paris: Flammarion, 1986;324-58.

20 Roca J, Rodriguez-Roisin R, Cobo E, Burgos F, Pérez J, Clausen JL. Single-breath carbon monoxide diffusing capacity $\left(\mathrm{DL}_{\mathrm{CO}}\right)$ prediction equations for a Mediterranean population. Am Rev Respir Dis 1990;140:1026-32.

21 Xaubet A, Rodriguez-Rosin R, Bombin A, Roca J, AgustiVidal A. Correlation of bronchoalveolar lavage and clinical and functional findings in asbestosis. Am Rev Respir Dis 1986;133:848-54

22 Roca J, Segarra F, Rodriguez-Roisin R, Cobo E, Martinez J,
Agusti Vidal A. Static lung volumes and single-breath diffusion capacity reference values from a latin population (abstract). Am Rev Respir Dis 1985;131:A352.

23 Roca J, Sanchis J, Agusti-Vidal A, et al. Spirometric reference values for a Mediterranean population. Bull Europ Physiopathol Respir 1986;22:217-24.

24 Xaubet A, Roca J, Rodriguez-Roisin R, et al. Bronchoalveolar lavage cellular analysis and gallium lung scan in the assessment of patients with amiodarone-induced pneumonitis. Respiration 1987;52:272-80.

25 Tukianen P, Taskinen E, Holsti P, Korhola O, Valle M. Prognosis of cryptogenic fibrosing alveolitis. Thorax 1983;38:349-55.

26 King TE, Dunn TL. Connective tissue disease. In: Schwarz MI, King TE Jr, eds. Interstitial lung disease. Toronto: BC Becker Inc, 1988:171-210.

27 Keogh BA, Crystal RG. Pulmonary function testing in interstitial pulmonary disease. What does it tell us? Ches 1980;78:856-64.

28 Agusti AGN, Roca J, Gea J, Wagner PD, Xaubet A, Rodriguez-Roisin R. Mechanisms of gas exchange impairment in idiopathic pulmonary fibrosis. Am Rev Respir Dis 1991;143:219-25.

29 Steen VD, Owens GR, Fino GJ, Rodnan GP, Medsger GA Pulmonary involvement in systemic sclerosis (scleroderma). Arthritis Rheum 1985;28:759-67.

30 Colp CR, Riker J, Williams H. Serial changes in scleroderm and idiopathic interstitial lung disease. Arch Int Med 1973;132:506-15.

31 Peters-Golden $M$, Wise RA, Schneider P, Hochberg M Stevens MB, Wigley F. Clinical and demographic predictors of loss of pulmonary function in systemic sclerosis. Medicine 1984;63:221-31.

32 Schneider PD, Wise RA, Hochberg MC, Wigley FM. Serial pulmonary function in systemic sclerosis. Am J Med 1982;73:385-94.

33 Steen VD, Owens G, Redmond R, Rodnan GP, Medsger RA $\mathrm{Jr}$. The effect of $\mathrm{D}$-penicillamine on pulmonary findings in systemic sclerosis. Arthritis Rheum 1985;28:882-8.

34 Frank ST, Weg JG, Harkleroad LE, Fitch RF. Pulmonar dysfunction in rheumatoid disease. Chest 1973;63:27-30.

35 Schwartz MI, Matthay RA, Sahn SA, Standford RE, Marmorstein BL, Scheinhorn DJ. Interstitial lung disease in polymyositis and dermatomyositis: Analysis of six cases and review of the literature. Medicine 1976;55:89-104.

36 Wiedemann HP, Matthey RA. Pulmonary manifestations of the collagen vascular diseases. Clin Chest Med 1989; 10:677-722.

37 Turner-Warwick $M$. Systemic arterial patterns in the lun and clubbing of the fingers. Thorax 1963;18:238-50.

38 Silver RM, Scott Miller K, Kinsella MB, Smith EA, Schabel SI. Evaluation and management of scleroderma lung
disease using bronchoalveolar lavage. Am J Med 1990; disease using

39 Rossi GA, Bitterman PB, Rennard SI, Ferrans VJ, Crysta RG. Evidence for chronic inflammation as a component of the interstitial lung disease associated with progressive systemic sclerosis. Am Rev Respir Dis 1985;131:612-7.

40 Garrett KC, Nugent $K$, Monick M, Hunninghake GW. Comparison of bronchoalveolar lavage (BAL) in patients with idiopathic pulmonary fibrosis (IPF-alone) and pulmonary fibrosis associated with a collagen vascular disorder (IPF-CVD) (abstract). Am Rev Respir Dis 1984; 129:A17.

41 Greene NB, Solinger AM, Baughman RP. Patients with collagen vascular disease and dyspnea. Chest 1987;91: 698-703.

42 Wallaert B, Hatron P, Grosbois JM, Tonnel AB, Devulder $B$, Voisin C. Subclinical pulmonary involvement in collagen-vascular diseases assessed by bronchoalveolar lavage. Am Rev Respir Dis 1986;133:574-80.

43 König G, Luderschmidt C, Hammer C, Adelmann-Grill BC, Braun $O$, Fruhmann G. Lung involvement in scleroderma. Chest 1984;85:318-24.

44 Hällgren $R$, Bjermer L, Lundgren $R$, Venge $P$. The eosinophil component of the alveolitis in idiopathic pulmonary fibrosis Am Rev Respir Dis 1989;139:373-7.

45 Peterson MW, Monick M, Hunninghake GW. Prognostic role of eosinophils in pulmonary fibrosis. Chest 1987;92:51-6. 